松永 大樹

大阪大学大学院基礎工学研究科

助教

機械学習による細胞力学環境の計測プラットフォーム構築

\title{
§1. 研究成果の概要
}

細胞は周囲の力学環境を感知し, その振る舞い(増殖・分化・アポトーシス)を大きく変える.バイ オエンジニアリング・再生医療分野では培養過程において細胞の振る舞いを制御することは重要 な課題であることから, “細胞”之“力学”の因果を明らかにするメカハバイオロジーの研究分野が注 目を集めている. 本研究課題では機械学習を融合した細胞収縮力の高速・自動解析プラットフォ 一ム構築を目指寸。

所属研究室 (大阪大学基礎工・出口研究室) はこれまでシワにより細胞の収縮力を可視化する独 自技術 [Fukuda et al. 2017; Ichikawa et al. 2017, J. Cell Sci] を開発してきた(図参照)が,シワ を自動的に抽出することが困難であった. そこで本研究課題の一歩目として, CNN (convolutional neural network）にシワの特徴を学習させ細胞の顕微鏡画像よりシワを自動抽出するシステムの開 発を行った.

CNN にシワの特徵を学習させるには, 訓練データとして「細胞の顕微鏡画像」と「シワの画像」が 必要となる. 従って手順(A)では画像処理技術を用い粗いシワの画像を生成し教師データとし, こ れら「顕微鏡画像」と「シワの画像」を用いて CNN にシワの特徵を学習させた. 最終的に完成した CNNを用い, 手順(B)のようにCNN のみによってシワの自動抽出が実現できた. 機械学習で得ら れたシワは, 画像処理のみで抽出したシワより遥かに明膫であり約 91 倍の正解率(正解データは 手作業で抽出したもの)を記録した. 現在, 以上の成果を国際学術誌に投稿中である. 
Step A. Learn features of wrinkles
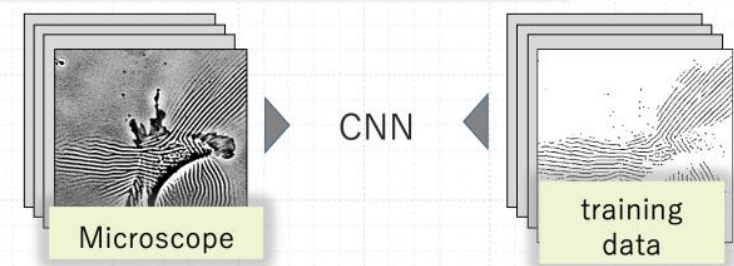

Step B. Wrinkle extraction
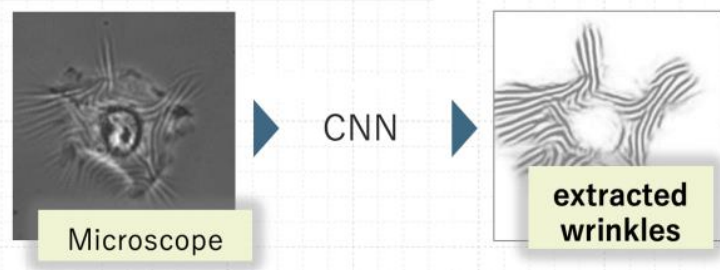